\title{
Challenges of Creation and Implementation of Collaborative Innovations in Public Sector Organisations
}

\author{
Adomas Vincas Rakšnys \\ Business Innovation Department \\ Vilniaus Kolegija University of Applied Sciences (VIKO) \\ Didlaukio. Str. 49, LT-08303, Vilnius, Lithuania \\ Andrius Valickas \\ Institute of Leadership and Strategic Management \\ Mykolas Romeris University \\ Ateities str. 20, LT-08303, Vilnius, Lithuania \\ Vilnius University Business School \\ Sauletekio av. 22, LT-10225 Vilnius, Lithuania \\ Ramūnas Vanagas \\ Institute of Leadership and Strategic Management \\ Mykolas Romeris University \\ Ateities str. 20, LT-08303, Vilnius, Lithuania \\ cross $^{\text {ref }}$ http://dx.doi.org/10.5755/j01.ppaa.19.1.25989
}

\begin{abstract}
Innovation in the public sector is inseparable from the political, administrative and technological components and stages of public administration systems development. Purpose of the article is to analyse and define the emerging concept of collaborative innovation in the public sector and indicate the major challenges relating to their generation and implementation. Benchmarking, generalisation and synthesis will be used as the methods in order to achieve the purpose of the article. Contemporary challenges of public governance lead to the change of the concept and operational principles of public sector organisations and encourage the need for innovation. The traditional, hierarchical innovation development conception is changed by collaborative innovation, which is characterised by networking, promotion of creativity and unification of resources. Significant principles for effective collaborative innovation become inter-organisational trust, knowledge sharing, informal leadership, ensuring the necessary resources and conditions for experimentation. Application of collaborative innovations requires adaptation to the changing positions of power and transformation of traditional roles of public sector employees.
\end{abstract}

Keywords: Collaborative innovation, public sector, new public governance, networks.

Raktažodžiai: Bendradarbiavimu grịstos inovacijos, viešasis sektorius, naujasis viešasis valdymas, tinklai

JEL classification: $H 83, O 3$.

\section{Introduction}

The current evolution of public administration systems involves various past and current challenges. Firstly, it should be mentioned such macro challenges as increasing fiscal pressures, political and cultural instability, population ageing, the spread of diseases, the refugee crisis, problems 
caused by global warming, technologisation trends, development of public service and increasing citizens' knowledge and expectations in respect of public sector organisations (Crosby et al., 2016; McNabb, 2009; Pollitt, 2016; Torfing et al., 2016). Micro and meso level processes should also be considered, such as redundancies and increasing migration of public sector staff to the private sector, which causes a decrease of professionalism and knowledge in public service. Lack of flexibility and creativity of public sector systems, which manifests itself as hyperpolarisation of rational procedures and processes, should also be emphasised. This is an integral part of the Rechtsstaat administrative culture and the resulting bureaucratic organisational culture determining resistance against the implementation of change strategies, programs and projects (Agger, Sørensen, 2016; McNabb, 2009; Pollitt, Bouckaert, 2011). Therefore we will base on the assumption in the article that under contemporary conditions, complex, unmanageable problems cannot be solved on the foundations of standard, rational decisions and just bureaucratic perspective on public sector organisations.

It becomes imperative to unite efforts, to rely on creative, cooperation-based and innovative solutions that could help find answers to the XXI national and global challenges of public governance (Crosby et al., 2016; Sørensen, Torfing, 2016). Therefore, increasingly more attention is paid to various interested parties, representatives of business and non-governmental organisations, as well as to local communities, as potential catalysts and developers of public governance innovations (Borins, 2014; Godenhjelm, Johanson, 2016). Thus, it is emphasized that in order to respond to the growing challenges in public governance, innovation becomes a more and more important topic of public administration discourse. It comprises the change of innovation concept, the analysis of challenges of innovation implementation in the transition from the traditional understanding of innovation linked to the hierarchical, political and administrative dimension, to the creation of collaborative innovation (Agger, Sørensen, 2016; Torfing et al., 2016).

However, innovation in the public sector is an extremely complex phenomenon, because it is inseparable from the political, administrative and technological components and different stages of development of public administration. Therefore the purpose of the article is to analyse and define the emerging concept of collaborative innovation in the public sector and indicate the major challenges relating to their generation and implementation. Benchmarking, generalisation and synthesis will be used as the scientific methods in order to achieve the purpose of the article.

\section{Development and challenges of the concept of innovation in the public sector}

The concept of innovation in the public sector is very specific, and its objectives, content and promotion are different from the innovation in the context of the private sector (Godenhjelm, Johanson, 2016; Pollitt, 2011). Therefore it is rational to sustain an argument of Laegreid et al. (2011) who describes innovation in the public sector as an ambiguous concept. Examining of the evolution of this concept from the historical perspective it can be pointed out that one of the functions of the public sector organisations was the promotion of programs that focused on the implementation of innovation in private sector organisations (Hansson et al., 2014). It is widely accepted that public sector organisations are characterised by lack of competition, and most of their processes are incremental in nature (Bekkers et al., 2011). Moreover, most of the innovation researches were private rather than public sector-oriented (Windrum, 2008). Thus it can be assumed that this led to the formation of the incorrect attitude that public sector organisations are less innovative than organisations operating in the private sector (Fuglsang, Pedersen, 2011) and that innovation has never been the norm in public sector organisations (Crosby et al., 2016). On the other hand, some scholars call this negative attitude to innovation in the public sector, not even a misinterpretation, but merely a myth (Sørensen, Torfing, 2016). Therefore, despite various development stages and different challenges of innovation in public sector organisations, innovation is a phenomenon that remains and continues to require increasing attention (Borins, 2014).

Firstly, it is important to highlight the distinctions between the concepts of innovation and change when analysing public sector innovations. It is often a case in the political and administrative discourse, in order to win public or staff affection when the newly elected politicians or heads of 
organisations interpreted any changes in programs as innovation, but these concepts differ in content. Changes and innovations are just partially coinciding phenomenon. Change is a broader phenomenon emphasizing continuity and conservation of traditional knowledge and practices in the presence of some developments in the examined sphere. Whereas innovation marks a break from the past, it can be seen as a form of discontinuous change (Agger, Sørensen, 2016; Osborne, Brown, 2005). Other academics are likely to accept this position, e. g. Bekkers et al. (2006) claim that innovation always requires change. However, not all changes are necessary must be considered as innovative. Also, it is important to distinguish the concept of innovation from the concept of the invention, emphasizing that innovation is particularly related to specific contexts. Certain methods applied in public sector organisations which determine distance from the practices of the past do not have to be brand new to be called an innovation. Significant factor becomes their adaptation and novelty in the specific context in which they were not previously applied. However, the concept of the invention relates to something completely new (Agger, Sørensen, 2016; McNabb, 2007; Sørensen, Torfing, 2011; Sørensen, Torfing, 2016).

The complicated concept of innovation in public sector organisations can be attempted to be explained based on very complex specifics of public administration. Public sector system is closely associated with the politics, private sector and non-governmental organisations. The goals of public sector organisations are concrete according to the direction of the implemented public policy. Therefore, the content and demand for innovation may differ significantly. It would be wrong to relate innovation in the public sector only to technological innovation (McNabb, 2009). It is important to distinguish innovative ideologies, strategies and programs, product and service innovation. Therefore Hartley (2005), summarising the positions of various scholars in regard of innovation in the public sector, distinguish these typologies of innovation: i) product innovation; ii) service innovation; iii) process innovation; iv) strategic innovation; vi) governance innovation; vii) rhetorical innovation. These typologies provide explanatory power when analysing the content and existing differences of innovation in the public sector. According to Bekkers et al. (2011), innovation in the public sector could also be described as a learning process in which public sector organisations are trying to meet the specific social challenges when developing and introducing new services, technologies, organisational structures, governance techniques and processes and concepts of policy. The range of examples of innovation in the public sector is extensive, from ISO standards to the Balanced Score Card (Verhoest et al., 2010). It is also widely accepted that innovation in the public sector can lead to an increase in the quality of public services and a decrease in public spending (Sørensen, Torfing, 2016). It can also contribute to social welfare, growth of labour productivity, technological progress and long-term job demand creation (Windrum, 2008).

Other authors conceptualising innovations tend to emphasise moral rather than instrumental dimension, without limiting the concept of innovation within the boundaries of the organisation. According to Moore and Hartley (2010), innovation in public governance is not limited to the boundaries of organisations. The innovation aims to build network-based finance, decision making and implementation systems, to use the new resource, to exploit the state's ability to ensure the rights of an individual. Therefore, innovation should be treated according to how it promotes justice and social development, as well as to its efficiency and effectiveness in achieving collectively set objectives.

When interpreting the complexity of innovation, it is necessary to mention the fact that the concept of innovation in the public sector is highly dependent on the specific modernisation reforms. Some scholars (Anttiroiko et al., 2011; Borins, 2014; Hansson et al., 2014) note that innovation in the public sector is primarily associated with the wave of New Public Management modernisation reform. New Public Management is a set of public sector modernisation reforms characterised by the principles of deregulation, entrepreneur activities, result orientation, competition, privatisation, outsourcing, contracting, greater manager autonomy (Borins, 2014; Laegreid et al., 2011; McNabb, 2009; Sørensen, Torfing, 2011). 
The connection between innovation and new public management modernisation can be interpreted based on the fact that until global reforms' movement of 1980, opportunities for innovation on the part of public sector managers and administrators have been extremely limited by the traditional model of public administration and definitely lacked certain stimulus (McNabb, 2007). This stimulus can be interpreted primarily in terms of financial motivation because, until New Public Management modernisation reforms, efficient performance and remuneration mechanisms in public service have not been developed (Laegreid et al., 2011). It can be stated that this modernisation phase of public sector organisations has created conditions to highlight political and service entrepreneurs, who challenged traditional roles of public sector employees and understanding of risk. Nevertheless, it should be noted that social responsibilities, accountability and legal factors restricted their opportunities (Windrum, 2008).

Thus it is noteworthy that even innovative initiatives in the context of New Public Management did not avoid criticism. Individuals' innovative motivation was often interpreted not as public interest, but as individual self-promotion, highlighting the ignorance of political subordination and administration tradition (Borins, 2014). Nevertheless, it must be recognized that in the past two decades, most of the innovation in the public sector was certainly based on market or quasi-market theories and concepts. Innovation was focused on macro innovation as the transformation of structures, administrative routines, organisations and budgets (Bozeman, 2007; Hansson et al., 2014).

However, not all scholars agree that innovation in the public sector should be considered solely in the context of New Public Management. According to Bekkers et al. (2011), implementation of innovation should not be associated exclusively with the aims of New Public Management modernisation reforms. The content of the concept of innovation is more complex and should not be solely restricted to the context of economic optimisation. Nevertheless, it is necessary to recognise that innovation should be seen as a necessary condition for the modernisation reforms (Bekkers et al., 2006). Hence, it can be deduced that innovation in public sector organisations should not be considered as a completely new phenomenon (Pollitt, 2011; Sørensen, Torfing, 2011). It was specified by Pollitt (2011), who claimed that innovation was not something new, despite the fact that in the past not everything might have been called innovation, it must be recognised that in the historical context innovation was promoted and adapted by the public bodies.

The research shows that cooperation has its advantages and disadvantages regarding the process of innovation created in the public sector (see Table 1).

Table 1. The peculiarities of cooperation in the process of the innovation creation

\begin{tabular}{|l|l|}
\hline EFFECTIVE & INEFFECTIVE \\
\hline The main objective & One partner is responsible for everyone \\
\hline Everyone contributes & Unclear accountability \\
\hline Recognition of everyone's contributions & $\begin{array}{l}\text { The belief that anything can be done during the part-time } \\
\text { job (half time job) }\end{array}$ \\
\hline The sufficiency of resources & The concealment of the agenda \\
\hline The clarification of the roles & \\
\hline
\end{tabular}

Note. Lank (2006)

\section{Implementation of innovation in the public sector and aspects of their politicization}

After reviewing the concept of innovation in public sector organisations, it is important to draw attention to the challenges of their implementation. From the procedural viewpoint, innovation can be described in three significant cycles: i) invention; ii) implementation; iii) diffusion (Osborne, 2002). According to the traditional public administration approach, the implementation of public sector innovation is closely linked to the initiative of top-level managers, top-down principle and centralisation (Fuglsang, Pedersen, 2011). As revealed by various studies, although decentralised 
organisations may be more effective for generating ideas, hierarchical and centralised organisations are more effective in the efficient implementation of innovation (Osborne, 2002). This method is one of the most frequently mentioned in media (Windrum, 2008). On the other hand, implementation of innovation is related not only to the structures of organisations and decision-making dimension but also to other elements. According to Edwards (2006), we can distinguish the following factors: i) external pressure to improve performance; ii) organisational culture that is favourable to innovation and learning; iii) trust development; iv) knowledge and competencies. According to Laegreid et al. (2011), significant factors of innovation are becoming the size of the organisation, organisational culture, as well as political-administrative culture, stage of development and purpose of functioning. According to McNabb (2009), the formation of appropriate organisational culture in public sector organisations should be one of the first steps for the effective implementation of innovation.

However, when analysing the implementation processes from the perspective of traditional public administration based on the above criteria, we can face different kinds of problems. First of all, it becomes important to define the most common administrative culture, which determines the formation of organisational culture. Pollitt and Bouckaert (2011) distinguish two essential administrative cultures (traditions): Rechtsstaat perspective, relating to the importance of legal methods, and the perspective of public interest, inherent in Anglo-Saxon countries. According to Bekkers et al. (2011), representational elements of Rechtsstaat perspective are bureaucratic organisational culture and such values as standardisation and formalisation, the importance of the law (equality against the law and legal security). In this perspective, public sector organisations are characterised by highly developed bureaucratic structure and centralisation. Public interest perspective is characterized by the fact that the role of the state in society is not as much elaborated and developed. Civil servants are treated as ordinary citizens who work for the state organisations, they are undistinguished by special status or mission, they rely more on managerial rather than only legal methods, and organisational structures are usually decentralised (Pollitt, Bouckaert, 2011).

Thus, we can conclude that in the countries characterised by Rechtsstaat administrative culture, implementation of innovation could be more effective because of centralisation, than in the countries characterised by decentralisation and public interest culture. On the other hand, it is necessary to recognize such limitations of Rechtsstaat culture as greater resistance to change and lower risk tolerance. Also, more significant political regulation should be emphasised, which creates very restricted conditions for the implementation of innovative programs (Bekkers et al., 2006; Hansson et al., 2014). Therefore, in order to achieve effective innovation and their implementation in public sector organisations, it is essential to transform the bureaucratic organisational culture to continuous learning culture (McNabb, 2007).

The administrative cultures of public interest and their conditioned decentralised structures are characterised by the fact that, unlike the Rechtsstaat perspective, they have more favourable conditions to form an innovative organisational culture. In accordance with the position of Borin (2014), it is significant to develop innovative organisational culture by rewarding and protecting innovators. This protection is necessary because innovation and its implementation is an unpredictable process (Sørensen, Torfing, 2011). Other authors also tend to confirm and emphasise the need for innovative organisational culture in public sector organisations. According to Agger and Sørensen (2016), innovation theory finally reveals the need to develop an organisational culture of innovation, which would promote creativity, experimentation and attention to the generation of innovative results. The advantages and disadvantages of administrative and organisational cultures are also an integral part of the phenomenon, which is called 'innovation paradox' in the academic discourse (Veenswijk, 2005). According to Veenswijk (2005), innovation is seen as a precondition for the provision of public services to citizens; it requires liability and risk-taking from public organisations and civil servants. However, at the same time, these factors disrupt the traditional roles of civil servants, which are inextricably linked to regulation standardisation and neutrality. On the other hand, this paradox, as a phenomenon in public administration, is relevant not only in the perspective of innovation. According to Anttiroiko et al. (2011), the search for balance between 
market orientation and democratic values, techno-optimism and radical environmental protection can be noted.

Another important argument to highlight the importance of experimentation and creativity in innovative creations and implementation is that innovation will not necessarily condition desired results or will be successfully implemented. The risk of unsuccessful innovation can lead to the end of the career of a particular individual who is initiating innovation. According to Sørensen and Torfing (2016), a large number of innovation fail or do not achieve the desired results. Failure of innovation may result in ruining political and administrative careers and cause storms in media and citizens' protests because their consequences, in contrast to the private sector, could have negative effects to the society as a whole. On the other hand, it is extremely difficult to predict the consequences of innovation. According to Agger and Sørensen (2016), during the process of public planning, the evaluation of innovation influence is not only important but also an extremely complex task because innovation can affect a wide range of factors related to the creation of public value. Their short-term and long-term impact may differ substantially. Nevertheless, it must be recognised that the size of the public sector and its ability to absorb the cost of failure could help reduce risk-avoiding behaviour (Sørensen, Torfing, 2011). Additionally, as Anttiroiko et al. (2011) rightly point out, despite the fact that some of the innovations will inevitably fail, the ability to learn from mistakes, as well as from the success, can lead to the successful implementation of innovations to public sector organisations, consumers, stakeholder groups and communities and will generate substantial public value. It is also necessary to recognise that the evaluation of the results of innovation is highly dependent on the perspective and chosen criteria of stakeholders. Furthermore, it is challenging to combine the interests of different structures participating in processes of networking (Agger, Sørensen, 2016; Godenhjelm, Johanson, 2016; Sørensen, Torfing, 2016).

When analysing the challenges for innovation in public sector organisations, it is important to recognise the issue of politicization of innovations. According to Hansson et al. (2014), the political aspect, especially emphasising regulation, can be regarded as an obstacle to the implementation of innovation. According to Pollitt and Bouckaert (2011), certain innovation can foster civil servants' mistrust because it is initiated by a specific political party. Therefore, it can be assumed that this dissatisfaction can manifest itself as an imitation of administrative processes and delay of political decisions relating to certain innovations. The political aspect is also significantly associated with the need for public sector innovation and legitimisation in society. Verhoest et al. (2010) describe this process by claiming that the introduction of new governance tools and other innovation into public sector organisations has a symbolic function to strengthen social legitimating. In these situations, means of governance can be on the surface of the organisation; however, they might not be used in daily activity. It is significant to emphasise the fact that, from the political point of view, innovation as a phenomenon may not necessarily be welcomed. In certain societies taking into consideration the characteristics of national culture continuity, predictability and trust are considered as much more significant factors than innovations (Pollitt, Bouckaert, 2011).

The political aspect is significant when analysing innovations and barriers in the public sector because of the issues and conflicting objectives of various interested parties. These aspects create complex and very different innovation promoting factors (Windrum, 2008). On the other hand, the involvement of various stakeholders is relevant because of the nature of innovations in public sector organisations, which is strongly related to the development of new knowledge. According to Hansson et al. (2014), the public sector is dominated by services rather than physical products. Therefore, innovation is often completely or partially based on such intangible factors as knowledge. However, in the modern stage of development of public administration, the sources of this knowledge could not exclusively be public sector organisations, but also other organisations participating in the processes of networking. Consequently, the concept of collaborative innovation is increasingly becoming important (Agger, Sørensen, 2016; Godenhjelm, Johanson, 2016; Sørensen, Torfing, 2011).

Summarising, it can be stated that public sector organisations are innovative in essence, regardless of the existing different types of barriers and formed negative approaches. Innovation in 
public sector organisations should not be limited to merely the economic or technological context of New Public Management. It can be assumed that innovation as a phenomenon in the public sector will continue to be a significant component of the processes of modernisation. The next section of the article will be devoted to the analysis of the concept and challenges for collaborative innovation.

In order to create innovation through interaction models between different organizations, certain processes and queues need to be maintained (see figure 1).

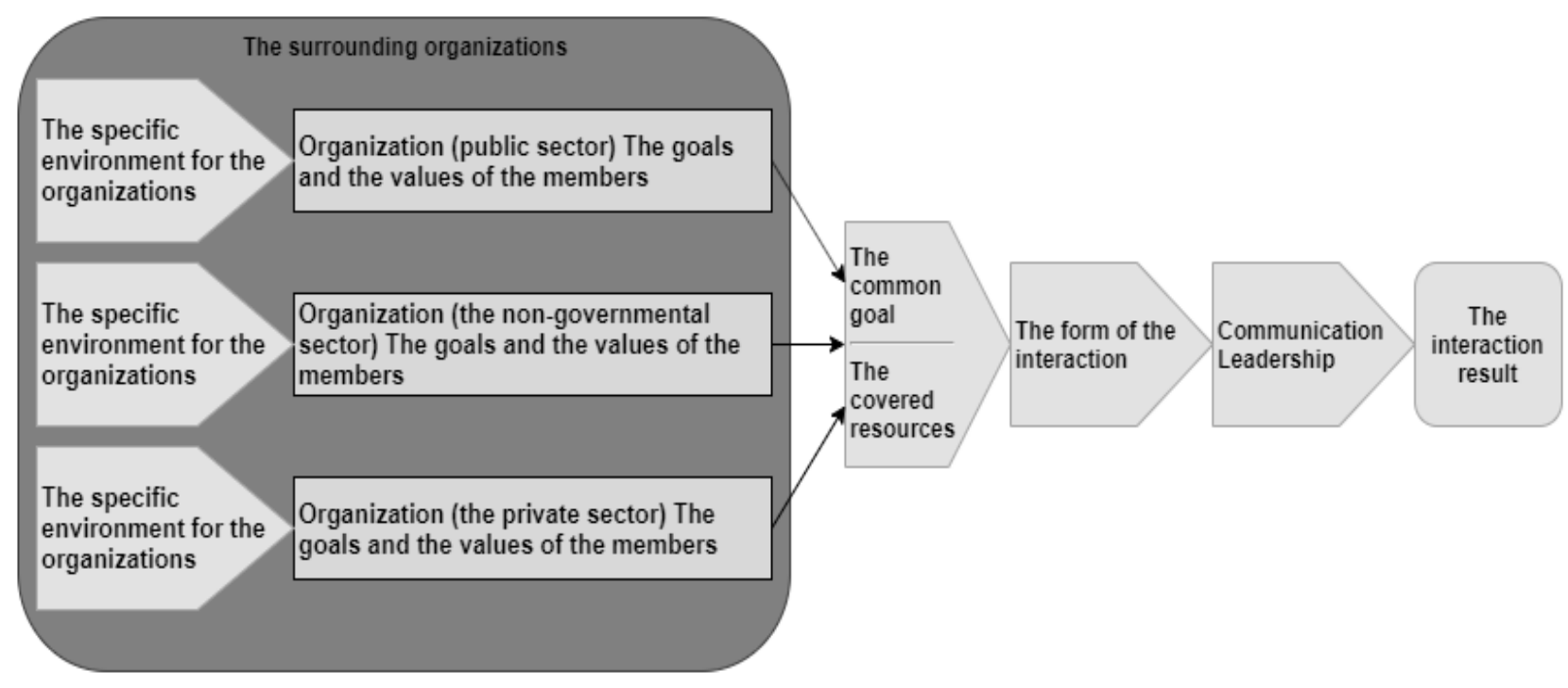

Fig.1. The structural model of the integrational cooperation

Source: Raišienè A. G. (2009).

\section{Creating collaborative innovation in the context of New Public Governance}

The concept of the contemporary state, functions and principles of operation of public organisations are significantly changed comparing to the traditional public administration and New Public Management era. The current phase of the modernisation of public sector is defined as a shift from the principles of the traditional public administration and New Public Management to the New Public Governance or, simply, the concept of the Network State (Anttiroiko et al., 2011; Pedersen, Tangkjaer, 2013). This phase is characterised by networking, flexibility, cooperation, openness and transparency rather than competition between stakeholders, interested in the implementation of public policy and creation of public value (Godenhjelm, Johanson, 2016; Pedersen, Tangkjaer, 2013; Torfing, Triantafillou, 2013). This concept of Network State is an alternative to the development of innovation in order to deal with the dysfunctions of traditional public administration and New Public Management. It is based not on the principles of hierarchy or market, but cooperation (Sørensen, Torfing, 2011). Collaborative innovation in the public sector is a multidimensional process. It involves the interaction of many stakeholders from various sectors in order to share efforts in promoting innovation in the public sector in one or more phases of innovation (Agger et al., 2015).

Having conceptualised the phenomenon of collaborative innovation, it is also essential to answer the question relating to the advantages of this process. Firstly, cooperation in innovation allows sharing different experiences, ideas and innovative resources (Sørensen, Torfing, 2016). Therefore, the flexibility of interaction of public sector organisations in terms of all stakeholders becomes the essential component for the potential of innovation (Godenhjelm, Johanson, 2016). Furthermore, one of the most significant functions and advantages of collaborative innovation is the promotion of creativity (Crosby et al., 2016). 
It is only natural that ideological changes, along with the reorganisation and restructuring processes in public sector organisations, result in the changes of creation and implementation of innovation. Therefore, according to Hartley (2005), it can be said that the phenomenon of innovation and possibilities of its implementation in the public sector have a different content, which depends on the modernisation reforms of public administration or the context of the dominant model of public administration (see Table 2).

Table 2. Innovation and improvement in different conceptions of governance and public management

\begin{tabular}{|c|c|c|c|}
\hline & $\begin{array}{l}\text { 'Traditional' public } \\
\text { administration }\end{array}$ & 'New' Public Management & Networked governance \\
\hline Innovation & $\begin{array}{l}\text { Some large-scale, national } \\
\text { and universal innovations }\end{array}$ & $\begin{array}{l}\text { Innovations in organizational } \\
\text { form more than content }\end{array}$ & $\begin{array}{c}\text { Innovation at both } \\
\text { central and local levels }\end{array}$ \\
\hline Improvement & $\begin{array}{l}\text { Large step-change } \\
\text { Improvements in managerial } \\
\text { initially, but less capability } \\
\text { for continuous improvement }\end{array}$ & $\begin{array}{l}\text { Improvements in managerial } \\
\text { processes and systems. } \\
\text { Customer focus produces } \\
\text { quality improvements in some } \\
\text { services }\end{array}$ & $\begin{array}{c}\text { Aiming for both } \\
\text { transformational and } \\
\text { continuous improvement } \\
\text { in front-line services }\end{array}$ \\
\hline Role of policy-makers & Commanders & Announcers/commissioners & Leaders and interpreters \\
\hline $\begin{array}{c}\text { Role of public } \\
\text { managers }\end{array}$ & Clerks and martyrs & $\begin{array}{c}\text { Efficiency and market } \\
\text { maximizers }\end{array}$ & 'Explorers' \\
\hline Role of the population & Clients & Customers & Co-producers \\
\hline
\end{tabular}

Source: Hartley (2005)

According to the table, it can be claimed that innovation in traditional public administration, which was related to the concept of the welfare state, had a universalistic rather than particularistic approach. However, in the context of modernisation reforms of Anglo-Saxon New Public Management, the emphasis was made on ensuring the innovation in organisational systems and processes. It may be considered that this was determined by the specifics of the private sector, where the attention is focused on the transfer of individual practices of successful management. Increasingly more significant aspects of innovation in the context of Network governance become coordination of innovation at both central and local levels of government, the importance of joint development and cooperation. On the other hand, it is necessary to understand that the change of the concepts of management is incremental, so the pursuit of collaborative innovation still faces oppositional institutional logic, with special emphasis on hierarchical bureaucracy and networking-based cooperation principles of stakeholders (Agger, Sørensen, 2016). Public sector bureaucrats find it difficult to adapt to the changing positions of power and transformations of their role when they do not have a dominant role in the context of collaborative innovation (Crosby et al., 2016). It should be noted that cooperation is not always possible, and collaborative processes do not always condition the creation and implementation of innovation (Sørensen, Torfing, 2011).

It is necessary to emphasise that networking, in principle, is not a panacea (Torfing, Triantafillou, 2013). Not all networks are created based on equality. Certain innovation can provide advantages and benefits for specific interest groups, while others may even cause damage. Some function effectively, and others do not. The motivation of the stakeholders participating in networking processes also differs (Anttiroiko et al., 2011; O'Leary, Vij, 2012). It should be emphasised that not always the necessary stakeholders are involved in networks; functional objectives may be vague and poorly defined. It is also not easy to avoid conflicts and differences in organisational cultures. Public strategies and strategies of stakeholders participating in networking may also differ (Sørensen, Torfing, 2016).

Last but not least, the concept of Network State (New Public Governance) is normative in nature. In practice, the situation may arise in which citizens or other interested parties simply will not 
be willing or able to participate in collaborative processes (Torfing, Triantafillou, 2013). Agger and Sørensen (2016) distinguish the challenges for the development of collaborative innovation. These challenges arise from the different principles of management concepts: i) First, who should determine the objectives of the innovation process - public sector organisations or interested parties participating in the process of cooperation; ii) The second, the challenge arises from the strong focus of bureaucratic organisations on procedures and coordinating the results of collaborative innovation; iii) The third challenge stems from the distinguishing priorities in processes, whether priority should be given to stability and control or creativity and experimentation; iv) The fourth challenge is inseparable from the tensions between the internal goals of organisations and organisational goals of innovation. However, these are certainly not the only challenges. Bekkers et al. (2011) stress that due to the ongoing meta and macro challenges, the modern public sector lacks communication and useful interaction with various stakeholders. This phenomenon is attempted to be explained as the effect of globalisation, individualisation and liberalisation. Naturally, in order to achieve effective interaction, strengthening of cross-organisational trust becomes significant. The trust factor between various interested parties could be seen as a precondition for achieving innovation. Focusing on increasing trust, it is necessary to pay attention to the processes of knowledge creation and sharing, which are vital to the effective development of innovations (Vangen, Huxham, 2010).

It is important to mention that leadership is essential in order to establish and maintain effective network interaction between public sector organisations and other interested parties. Nevertheless, some authors (McNabb, 2007) doubt the success culture of public sector organisations, i.e., possibilities to attract strong and charismatic personalities to civil service, who can respond adequately, initiate and organise inter-organisational processes in the development of collaborative innovation. Besides, it should be noted that network interaction and development of collaborative innovation require new competencies from the leaders of public sector organisations (Pedersen, Tangkjaer, 2013).

On the other hand, it should be noted that in the processes of creation of collaborative innovation we should not be guided by only the approaches of the traditional public administration and New Public Management, where innovation leaders must be public sector servants or politicians who occupy a formal post. The function of leadership may also be collective and arise from a variety of stakeholders and not necessarily to be formal (Crosby et al., 2016). It should also be recognised that financial resources are also significant for effective cross-sectoral cooperation in the development of innovation. Financial resources can be seen as one of the means of motivating the stakeholders (Agger et al., 2015). It is also important to pay attention to the legal-political environment of public sector organisations. To encourage collaborative innovation, it is necessary to form an appropriate legal environment, to allocate the necessary resources for innovative experiments (Hartley, 2005).

The cross-sector integration not only helps to concentrate the resources and the reserves for the common good (commonwealth) but also increases the responsibility of integration actors, especially when the benefits and the risks are shared between them. The authors present the following positive aspects of intersectoral integration (see figure 2).

In summary, the Network State concept is characterised by the trends of democratisation in which various interested parties can contribute to the implementation of public policy. Development and implementation of innovation are based on collective interaction, and promote creativity, sharing of knowledge and resources, provide an opportunity to find solutions for extremely difficult and complex problems of modern public governance. 


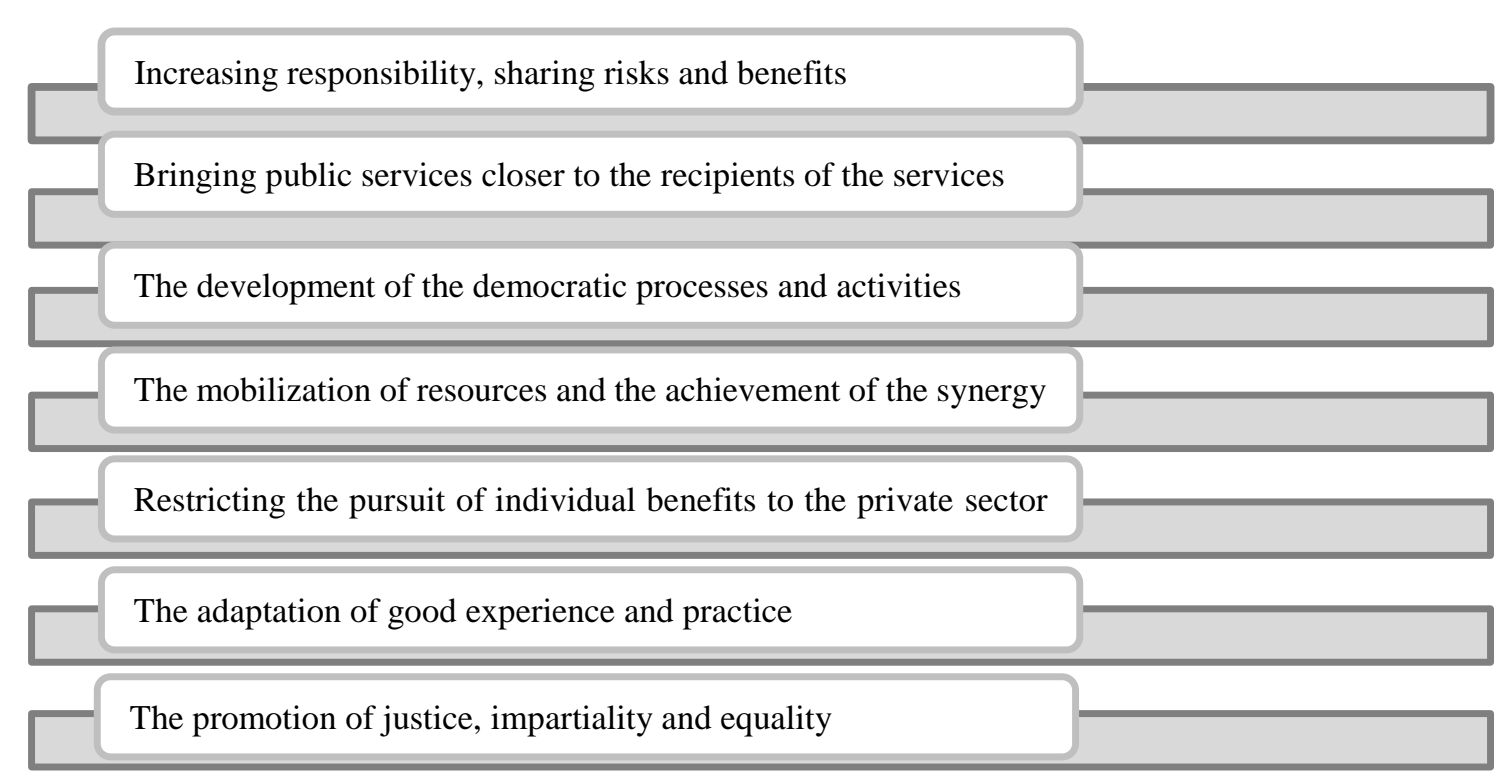

Fig.2. The positive aspects of the intersectoral integration

Source: Raišienè A. G. (2009) and Freeman R. E. (2007).

\section{Conclusions}

1. Innovation in public sector organisations is not a new phenomenon. Analysis of this concept should not be restricted to the context of economic optimisation originating from New Public Management modernisation reforms.

2. Contemporary challenges of public governance lead to the change of the concept and operation principles of public sector organisations and encourage the need for innovation. The traditional, hierarchical understanding of developing and implementation of innovation is changed by collaborative innovation, which is characteristic of New Public Governance. This concept is characterised by networking, promotion of creativity and unification of resources.

3. Significant principles for effective collaborative innovation become the formation of the appropriate legal and political environment, inter-organisational trust, knowledge sharing, informal leadership, ensuring the necessary resources and conditions for experimentation.

4. The intersectoral integration is a highly complex process which has a wide range of contextualities. With regard to the intersectoral integration, it is important to understand the potential of wide-range partnership possibilities in relation to other processes, the possibilities of decomposing various partnerships and eventually it is necessary to realize the objectives, the interactions (principles) of operations management and the importance of the cooperation

5. The key challenges for developing and implementation of collaborative innovation are bureaucratic resistance to change, fear to take risks, different motivations of stakeholders involved in innovation, organisational culture, lack of adequate human resources, and abstract or even conflicting goals. The investigation of the international students' experiences of public administration activity in the host country also revealed it to be a sensitive topic to a certain group of respondents. In respect to that, further scientific researches could also benefit from a qualitative type of methodological approach.

\section{References}

1. Agger, A., Damgaard, B., Hagedorn Krogh, A., Sørensen, E. Collaborative Governance and Public Innovation in Northern Europe. 1st Edition. Oak Park, US: Bentham E-Books, 2015. 
2. Agger, A., Sørensen, E. Managing collaborative innovation in public bureaucracies, Planning Theory, 2016, p. 1-21.

3. Anttiroiko, A.-V., Bailey, S.J., Valkama, P. Innovations in Public Governance in the Western World, In Innovations in Public Governance, (eds. Anttiroiko, A.-V., Bailey, S.J., Valkama, P.), 1st Edition. Amsterdam: IOS Press, Amsterdam, 2011.

4. Bekkers, V., Edelenbos, J., Steijn, B. An Innovative Public Sector? Embarking on the Innovation Journey, In Innovation in the Public Sector: Linking Capacity and Leadership (eds. Bekkers, V., Edelenbos, J., Steijn, B.). 1st Edition. Governance and Public Management Series. Basingstoke: Palgrave Macmillan, 2011.

5. Bekkers, V., Van Duivenboden, H., Thaens, M. Public innovation and information and communication technology: relevant backgrounds and concepts, In Information and Communication, Technology and Public Innovation: Assessing the ICTdriven Modernization of Public Administration (eds. Bekkers, V., van Duivenboden, H., Thaens, M), 1st Edition. IOS Press, Amsterdam, 2006.

6. Borins, S. F. The Persistence of Innovation in Government. 1st Edition. Brookings / Ash Center Series, Innovative Governance in the 21st Century. Washington, US: Brookings Institution Press/Ash Center, 2014.

7. Bozeman, B. Public Values and Public Interest: Counterbalancing Economic Individualism, 1st Edition. Washington, D.C.: Georgetown University Press, 2007.

8. Crosby, B. C., Hart, P., Torfing, J. Public value creation through collaborative innovation, Public Management Review, 2016, p. 1-15.

9. Edwards, A. Empowering Communities for Environmental Decision-Making: Innovative Partnerships in Cleveland (USA), In Information and Communication Technology and Public Innovation (ed. Bekkers, V.) 1st Edition. Amsterdam: IOS Press, Amsterdam, 2006.

10. Freeman R. E., Jeffrey S. Harrison, Andrew C. Wicks, Managing for stakeholders: survival, reputation, and success. New Haven (Conn.); London: Yale University Press, 2007.

11. Fuglsang, L., Pedersen, J. S. How Common Is Public Sector Innovation and How Similar Is It to Private Sector Innovation? In Innovation in the Public Sector: Linking Capacity and Leadership (eds. Bekkers, V., Edelenbos, J., Steijn, B.). 1st Edition. Governance and Public Management Series. Basingstoke: Palgrave Macmillan, 2011.

12. Godenhjelm, S., Johanson, J. E. The effect of stakeholder inclusion on public sector project innovation, International Review of Administrative Sciences, 2016, p. 1-21.

13. Hansson, F., Norn, M. T., Bundgaard, Vad T. B. Modernize the public sector through innovation? A challenge for the role of applied social science and evaluation, Evaluotion, 2014, Vol. 20, No 2, p. 244-260.

14. Hartley, J. Innovation in Governance and Public Services: Past and Present, Public Money \& Management, 2005, Vol. 25, No 1, p. 27-34.

15. Lank E. Collaborative Advantage: How organizations win by working together: Palgrave Macmillan UK, 2006.

16. Lægreid, P., Roness, P. G., Verhoest, K. Explaining the Innovative Culture and Activities of State Agencies, Organization Studies, 2011, Vol. 32, No 10, p. 1321-1347.

17. McNabb, D. E. Knowledge Management in the Public Sector: A Blueprint for Innovation, 1st Edition. New York, Armonk, 2007.

18. McNabb, D. E. The new face of government: How public managers are forging a new approach to governance. 1st Edition. BecaRaton: CRC Press, 2009.

19. Moore, M., Hartley, J. Innovation in Governance, In The New Public Governance (ed. Osborne, St.). London: Routledge, 2010.

20. O'Leary, R., Vij, N. Collaborative Public Management: Where Have We Been and Where Are We Going?, The American Review of Public Administration, 2012, Vol. 42, No 5, p. $507-522$. 
21. Osborne, S. P., Brown, K. Managing Change and Innovation in Public Service, 1st Edition. New York: McGraw-Hill Companies, Inc, 2005.

22. Osborne, S. P. Routledge Studies in the Management of Voluntary and Non-Profit Organizations: Voluntary Organizations and Innovation in Public Services, 1st Edition. London, US: Routledge, 2002.

23. Pedersen, D., Tangkjær, C. Building leadership capacity in the involving network state, Teaching Public Administration, 2013, Vol. 31, p. 29-41.

24. Pollitt, Ch. Be prepared? An outside-in perspective on the future public sector in Europe, Public Policy and Administration, 2016, Vol. 31, No 1, p. 3-28.

25. Pollitt, Ch. Innovation in the Public Sector: An Introductory Overview, In Innovation in the Public Sector: Linking Capacity and Leadership (eds. Bekkers, V., Edelenbos, J., Steijn, B.). 1st Edition. Governance and Public Management Series. Basingstoke: Palgrave Macmillan, 2011.

26. Pollitt, Ch., Bouckaert, G. Public Management Reform: A Comparative Analysis -New Public Management, Governance, and the Neo - Weberian State, 3rd Edition. Oxford: Oxford University Press, 2011.

27. Raišienè A. G., In Quest of Integrated Collaboration Inter- organizational interaction in the practice of Lithuania's Local Government, LAP Lambert Academic Publishing, 2009.

28. Sørensen, E., Torfing, J. Enhancing Collaborative Innovation in the Public Sector, Administration \& Society, 2011, Vol. 43, No 8, p. 842- 868.

29. Sørensen, E., Torfing, J. Metagoverning Collaborative Innovation in Governance Networks, American Review of Public Administration, 2016, p. 1- 19.

30. Torfing, J., Sørensen, E., Roiseland, A. Transforming the Public Sector Into an Arena for CoCreation: Barriers, Drivers, Benefits, and Ways Forward, Administration \& Society, 2016, p. $1-31$.

31. Torfing, J., Triantafillou, P. What's in a Name? Grasping New Public Governance as a Political-Administrative System, International Review of Public Administration, 2013, Vol. 18, No 2, p. 9-25.

32. Veenswijk, M. Cultural Change in the Public Sector: Innovating the Frontstage and Backstage In Organizing Innovation New Approaches to Cultural Change and Intervention in Public Sector Organizations (eds. Veenswijk, M.) IOS Press, the Netherlands, 2005.

33. Vangen, S., Huxham, C. Introducing the theory of collaborative advantage, In The New Public Governance (ed. Osborne, St.). London: Routledge, 2010.

34. Verhoest, K., Roness, P. G., Verschuere, B., Rubecksen, K., MacCarthaigh, M. Autonomy and Control of State Agencies Comparing States and Agencies, 1st Edition. Palgrave Macmillan, 2010.

35. Windrum, P. Innovation and entrepreneurship in public services In Innovation in Public Services: Entrepreneurship, Creativity, and Management (eds. Windrum, P., Koch, P.). Chelttenham, UK, 2008.

Adomas Vincas Rakšnys, Andrius Valickas, Ramūnas Vanagas

\section{Bendradarbiavimu grịstų inovacijų kūrimo ir igyvendinimo iššūkiai viešojo sektoriaus organizacijose}

\section{Anotacija}

Dabartinė viešojo administravimo sistemų evoliucija neatsiejama nuo ịvairių praeities ir dabarties iššūkių. Inovacijos viešajame sektoriuje kaip reiškinys yra itin kompleksinis ir sudètingas, nes jis yra neatsiejamas tiek nuo politinių, administravimo ir technologinių dedamujų, skirtingų viešojo administravimo vystymosi etapų. Straipsnyje yra siekiama apibrěžti naujai besiformuojančią 
bendradarbiavimu grịstų inovacijų koncepciją viešajame sektoriuje bei identifikuoti esminius jų generavimo ir plètros iššūkius. Tikslui pasiekti taikomi lyginamosios analizès, apibendrinimo ir sintezès metodai. Šiuolaikiniai viešojo valdymo iššūkiai sąlygoja viešojo sektoriaus organizacijų sampratos ir veiklos principų kaitą ir skatina inovacijų poreikį. Tradicinį, hierarchinị supratimą apie inovacijų kūrimą ir ịgyvendinimą keičia naujajam viešajam valdymui būdinga bendradarbiavimų grịsta inovacijų kūrimo koncepcija, pasižyminti tinkline sąveika, kūrybiškumo skatinimu ir resursų suvienijimu. Reikšmingais principais siekiant veiksmingo bendradarbiavimu grịstu inovacijų kūrimui tampa tinkamos teisinès ir politinès aplinkos formavimas, tarp-organizacinis pasitikejjimas, žinių dalijimasis, neformali lyderystè, reikiamų resursų užtikrinimas ir sąlygų eksperimentavimui sudarymas. Esminiais iššūkiais bendradarbiavimu grịstų inovacijų kūrimui ir ịgyvendinimui laikytini valstybės tarnautojų ir kitų viešojo sektoriaus darbuotojų pasipriešinimas pokyčiams, baimè prisiimti riziką, skirtingos suinteresuotų pusių dalyvaujančių inovacijų kūrime motyvacijos, organizacinė kultūra, tinkamų žmogiškųjų išteklių stoka, abstraktūs ar net konfliktuojantys tikslai. Viešojo sektoriaus vadybininkams sudètinga prisitaikyti prie kintančių galios pozicijų ir jų vaidmens transformacijų, kuomet bendradarbiavimu grịstų inovacijų kontekste jie neužima dominuojančios pozicijos.

Adomas Vincas Rakšnys - Vilniaus Kolegijos (VIKO), verslo inovacijų katedros lektorius. Pagrindinès mokslinių tyrimų sritys viešojo sektoriaus modernizavimas, organizacinè kultūra, postmodernizmas.

email: e_cnv@yahoo.com

Andrius Valickas - Mokslų daktaras, Mykolo Romerio universiteto Lyderystès ir strateginio valdymo instituto profesorius ir Vilniaus universiteto Verslo mokyklos profesorius. Pagrindinès mokslinių tyrimų sritys yra vadyba, žmogiškujų išteklių valdymas, karjeros valdymas, socialinė teorija.

email: valickas.andrius@gmail.com

Ramūnas Vanagas - Mokslų daktaras, Mykolo Romerio universiteto Lyderystès ir strateginio valdymo instituto docentas. Pagrindinès mokslinių tyrimų sritys yra teisès ir vadybos teorinès bei praktinès žinios.

email: rvanagas@mruni.eu

Adomas Vincas Rakšnys - Lecturer at the Department of Business Innovation, Vilniaus Kolegija University Of Applied Sciences (VIKO). The main research areas are public sector modernization, organizational culture, postmodernism.

email: $\underline{\text { e_cnv@yahoo.com }}$

Andrius Valickas - PhD, professor of the Institute of Leadership and Strategic Management at Mykolas Romeris University (Lithuania) and professor of Vilnius University Business School (Lithuania). The main research areas are management, human resource management, career management, social theory.

email: valickas.andrius@ gmail.com

Ramūnas Vanagas - PhD, docent at the Institute of Leadership and Strategic Management at Mykolas Romeris University (Lithuania). The main research areas are theoretical and practical knowledge in law and management.

email: rvanagas@mruni.eu 